\title{
Management Factors Affecting the Establishment of Pine Based Silvopas- tures in Southern Grasslands in the United States
}

\author{
David Brauer ${ }^{*}, 1$, Henry Pearson ${ }^{2}$ and David Burner ${ }^{2}$ \\ ${ }^{1}$ USDA ARS CPRL, PO Drawer 10, 2300 Experiment Station Road, Bushland, TX 79012, USA \\ ${ }^{2}$ Dale Bumpers Small Farms Research Center/ ARS/ USDA, 6883 Highway 23, Booneville, AR 72927, USA
}

\begin{abstract}
Silvopasture practices are being advocated as a means of maintaining pine forest acreage in the southeast United States; however, scientific data on the design and management for optimum tree growth are lacking. Studies were conducted near Booneville AR to determine the effects of weed control, irrigation, soil fertilization and protection from cattle grazing on the establishment of loblolly pines (Pinus taeda L.). Pine seedling growth during the first year after planting was increased significantly by weed control in a factorial experiment in which pre-plant fertilization, irrigation and weed control were treatments. In a follow-up experiment, first-year pine regeneration was increased by a high level of weed control. Pine seedling survival and growth up to 21 months after transplanting were significantly reduced when seedlings were planted into pastures grazed continuously by cattle. These results demonstrate the need for regulated grazing systems during pine regeneration and establishment of silvopastures and that pine growth is best when competing vegetation is minimal.
\end{abstract}

\section{INTRODUCTION}

The future for pine based forest lands in the southeast United States remains promising [1]. A lack of increases in federal cost share programs for pine tree planting and higher establishment costs may deter private landowners from planting pine forests at the rate that was observed in the previous 20 to 30 years. These conditions, however, may increase the attractiveness of converting pasturelands into silvopastures. Cost share programs for agroforestry plantings can provide alternatives to forestry based programs. Fewer trees planted per land area for agroforestry practices will partially offset rising establishment costs. In addition, establishment of agroforestry practices, specifically silvopastures, may have other benefits, like increased wildlife habitat, that will make their adoption more appealing. Recent economic analyses indicate that the profitability of silvopasture systems in the southeast United States is similar to other land uses [2], but has greater potential for income from hunting leases than traditional forestry planting. Other analyses indicate that income from the tree component of the silvopasture practice contributes more to the profitability of the operation than the cattle component $[3,4]$, although the cattle component provides annual income. These results suggest that the profitability of silvopasture for the soils and climate of the southeastern United States is greatest when the management practice favor the production of the tree component.

The success of a silvopasture practice is in part determined by the ability of the trees to establish on the site. Tree establishment is influenced by the competitiveness of the introduced tree species for nutrients, water and light. Newly planted trees may have insufficient solar irradiation for

\footnotetext{
*Address correspondence to this author at USDA ARS CPRL, PO Drawer 10, 2300 Experiment Station Road, Bushland, TX 79012, USA;

E-mail: david.brauer@ars.usda.gov
}

optimum growth when either planted into partially deforested landscapes or when competing herbaceous weeds are taller than the trees. After trees have become established, it is more likely that growth in the understory will be limited by reduced solar irradiation. Burner and Belesky [5] found that solar irradiation limited the productivity of tall fescue ( $\mathrm{Lo}$ lium arundinaceum Schreb.) growing in the understory of loblolly pines (Pinus taeda_L.) planted at 620 tree per ha. These authors concluded that silvopastures must be managed to provide sufficient solar irradiation for optimum understory growth. Competition for nutrients and water can be intense when planting trees into pastures, because of the perennial nature of pasture species and the persistence of seeds produced that have become adapted to the existing ecosystem. Competition between the planted trees, and existing and emerging vegetation can decrease tree survival, and growth.

There is an on-going debate as to whether soil nutrients or moisture is the most limiting resource affecting tree establishment. Adams et al. [6] and Davis et al. [7] investigating the effects of supplement irrigation on the success of tree establishment indicated that competition for soil moisture determined the success of tree establishment to a greater extent than competition for nutrients. Relatively fast growing hardwood tree species were utilized in both of these studies at locations in which potential evapotranspiration $\left(\mathrm{ET}_{\mathrm{o}}\right) \mathrm{ex}-$ ceeded precipitation (PREC). Other researchers concluded that eliminating competing herbaceous weeds resulted in higher soil moisture [6-9] and thus reduced the level of competition for soil moisture between establishing trees and other plant species. It seems likely that competition for soil moisture will occur during the establishment of trees into existing pastures in the southeast United States because there are periods during the year in which potential $\mathrm{ET}_{\mathrm{o}}$ exceeds PREC, and the water storage capacity of these soils tend to be low to moderate. Competing vegetation can be eliminated or reduced by mechanical cultivation procedures, application 
of herbicides installation of natural or synthetic mulches or ground coverings, sometimes generically referred to as weed mats [10]. Effective control of weeds by mats has been reported for the establishment of ornamental and hardwood plantings [11]. Use of weed mat to control understory vegetation has been advocated as an integral part of a "plant and walk-away" establishment protocol [12]. Weed mat has been used successfully to control competing understory vegetation in establishing pines [13]. This may be a cost effective means of controlling weeds in the establishment of pine silvopasture practices because of its low cost per unit [8] and the relatively low density of trees planted.

Further evidence that competition for soil moisture is an important factor in tree establishment comes from experiments in which soil fertility treatments are imposed in a factorial arrangement with treatments that affect soil moisture, i.e., weed control or irrigation. Growth response of trees to increasing soil fertility was observed only in those situations in which soil moisture deficiencies were prevented or reduced [14-16], suggesting that competition for moisture tended to be more important than competition for nutrients.

Determining when to commence grazing is a major management decision when establishing a silvopasture practice. Lewis et al. [17] reported little impact of grazing on tree survival and growth if grazing was delayed 3 to 5 years after planting. However, many cattle producers in the southeast United States may not be able to delay grazing because farm herd size is close to the farm's capacity to produce forages. Research has indicated that 80 to $90 \%$ of the forage can be harvested for hay production during the establishment period of pines [17], thus providing an alternative means by which the forage could be utilized. A disadvantage of such an approach is feeding hay increases the expense of the cattle operation considerably. Relatively minor damage to pines was been observed when light rotational grazing by cattle was allowed [17-21]. Resistance of loblolly pines to damage from grazing may in part be due to a tap root structure in young trees [22], which provide firm anchorage in the soil and a lack of spreading roots that could be damaged by trampling actions of hooves. Many cattle producers do not practice rotational grazing schemes because the required infrastructure is relatively expensive. Cattle ranchers that practice a continuous grazing scheme and need the bulk of the forage on their farms to maintain cattle herd size need alternative techniques to establish silvopasture practices. Objectives of this study were to determine the effects of: weed control, irrigation, soil fertilization and treatments to prevent damage by cattle under a continuous grazing scheme.

\section{MATERIALS AND METHODS}

Site Characteristics. Experiments were conducted on the Dale Bumpers Small Farms Research Center, located about 6 $\mathrm{km}$ southwest of Booneville, Arkansas, United States (approximately N35.10 W94.00). The research center is located in a broad valley at an elevation of $130 \mathrm{~m}$ above sea level bordered by ridges that are the southern edge of the Boston Mountains. Annual PREC is approximately $1020 \mathrm{~mm}$. High air temperature and low rainfall typically result in soil moisture deficient for several weeks to months in late summer and early fall. Soils in these studies were either Leadvale
(Fine-silty, siliceous, semiactive, thermic Typic Fragiudults) or Enders (Fine, mixed, active, thermic Typic Hapludults) silt loam [23]. One difference between these two soil series is that the Enders silt loam tends to occur on more upland locations and lacks a fragipan, while the subsoil fragipan of the Leadvale silt loam can lead to waterlogging during wetter periods of the year. The regional deer population is relatively low; so damage from deer (Odocoileus virginianus) rubbing and herbivory is rare (data not shown). Improved loblolly seedling trees were obtained from the Arkansas Forestry Commission and selected for uniform height $(20 \pm 2 \mathrm{~cm}$ from trunk/root interface to apical meristem) and the occurrence of dominant terminal bud prior to planting for the three experiments described below. Selection for uniformity in height resulted in no statistical difference in tree height when measured immediately after planting in Experiments 1 and 2 (data not shown).

Experiment 1. Effects of weed control, irrigation and soil fertility on pine establishment. An experiment was conducted with a factorial design to determine the effects of preplant fertilization, supplemental irrigation and two levels of weed control. Half the trees received pre-plant fertilization, consisting of two packets (10 g of 16-6-8) of Right Start Fertilizer $^{\circledR 1}$ (Treessentials Company, Mendota Heights, MN) placed at the bottom of the hole prior to tree planting. Half the trees received supplemental irrigation by drip irrigation (one emitter delivering 3.8 liters per hour for $8 \mathrm{~h}$ ) if PREC was less than $25 \mathrm{~mm}$ in the previous 7 days. This rate of irrigation was chosen to supply approximately $25 \mathrm{~mm}$ of water assuming a rooting diameter of $1 \mathrm{~m}$. Two levels of weed control were imposed. The low level of weed control was accomplished by spraying over the top with Oust ${ }^{\circledR}$ (sulfometuron methyl, $0.2 \mathrm{~kg}$ active ingredient per ha) twice during the growing season (April to October). A high level of weed control was accomplished by using a landscape mat (0.7 x 0.7 m, DeWitt Pro5 Weed Barrier, Hummert International, Inc.) in addition to the Oust ${ }^{\circledR}$ applications. Common bermudagrass (Cynodon dactylon (L.) Pers.) was the plant species targeted for control by the herbicide application, because it was the dominant competing vegetation.

Herbicide (Oust ${ }^{\circledR}, 0.2 \mathrm{~kg}$ active ingredient per ha) was applied in a strip $1.2 \mathrm{~m}$ wide according to its label about two weeks prior to planting. Trees were planted by placing seedings into an augered hole, $0.6 \mathrm{~m}$ in depth and $0.3 \mathrm{~m}$ in diameter on April 6, 2001 in the middle of the strip to which herbicide had been applied and refilling the hole with the excavated soil. A visual inspection of the amount of competing vegetation in the area adjacent to trees was performed every two weeks. Bare ground or dead plant material occupied at least $85 \%$ of the surface area within $2 \mathrm{~m}$ of each tree over the growing season in the low weed control treatment (Fig. 1). Virtually all (>95\%) of the surface area within $2 \mathrm{~m}$ of each tree was bare ground, dead plant material or landscape mat in the high weed control treatment (Fig. 1). A plot consisted of three trees. There were five replications of eight treatment combinations.

Tree height was measured as the distance from the ground to the apical meristem just after planting, July 2001 and March 2002. Immediately after measuring tree height in March 2002, aerial portion of the tree was harvested by clipping the trunk at ground level and above ground tree fresh 


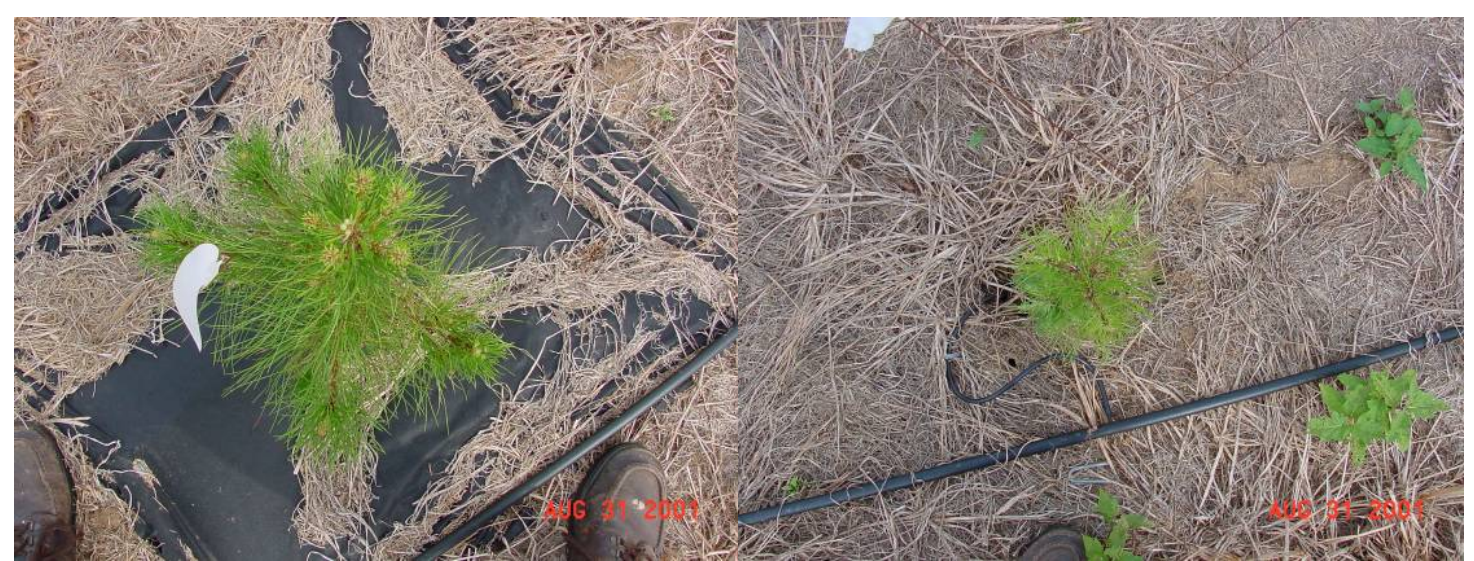

Fig. (1). Level of competing vegetation for the two levels of weed control. Photographs were taken on August 21, 2001. The left panel documents lack of competing vegetation where chemical weed control was supplemented with a weed mat. The right panel documents the amount of competing vegetation six weeks after mid-season application of chemical weed control. (Experiment 1).

weight was then measured. Tree fresh weight data were subjected to analysis of variance using PROC GLM of SAS [24] and a factorial design (2 levels each of weed control, irrigation and pre-planting fertilizer). Tree height data from the three dates were subjected to analysis of variance using PROC GLM [24] and a split plot design in which time after planting was the main plot and the factorial factors of weed control, irrigation and fertilization were the sub-plots. Least square means and standard errors (LSSE) were used for mean comparisons.

Experiment 2. Effects of weed control on loblolly seedling growth. A second experiment was conducted in 2002 to verify the effects of weed control on loblolly seedling growth. Site preparation was as above and the same field was utilized. Seedlings trees were planted into augered holes on April 2, 2002. Three weed control treatments were imposed, two being identical to those described above. For the third weed control treatment, the area within $30 \mathrm{~cm}$ of the tree seedling was covered to a depth of $10 \mathrm{~cm}$ with compost produced from logs that had been used to produce shiitake mushrooms as described by Kimmons et al. [25] immediately after tree planting, and Oust ${ }^{\circledR}$ was applied as in the other two treatments. Heavy rain showers soon after planting disturbed the integrity of the compost mat and no remediation actions were taken. Data collection was as in the first experiment except that survival and tree height were determined on April 3, June 11 and September 12, 2002, and tree fresh weight on September 12, 2002. Experimental design and statistical analyses were as for the first experiment except the number of replications was six.

Experiment 3. Protection from grazing experiment. Approximately two weeks prior to planting loblolly pine trees, a strip $1 \mathrm{~m}$ wide was sprayed with Oust ${ }^{\circledR}(0.2 \mathrm{~kg}$ of active ingredient per ha). Loblolly pine seedling trees were machineplanted into the middle of the Oust ${ }^{\circledR}$ treated strips at $1.2 \times 4.9$ $\mathrm{m}$ spacing in four tall fescue and four bermudagrass pastures between March 16 and 18, 1992. Oust ${ }^{\circledR}$ applications were repeated annually in June. Pastures were grazed year around by Brahman influenced beef cows and their calves. During the winter months supplemental hay was provided when forage availability was insufficient to maintain cows in good condition. Average calving date was middle of March and weaning occurred within 2 weeks of October 1. Forage utili- zation by grazing cattle averaged approximately $50 \%$ over the calendar year [26]. Nine rows of trees (45 $\mathrm{m}$ in length) were planted per pasture. The nine rows represented three replications of three tree protection treatments. The tree protection treatments were: 1) open grazing, i.e. no tree protection; 2) a single-wire electric fence directly over the newly planted pine seedling row; and 3) electric fence enclosure extending 0.7 to $0.9 \mathrm{~m}$ from both sides and ends of the pine seedling row. Total area planted to pines was approximately 0.2 ha within 17 ha pasture. Trees survival was determined $3,10,15$ and 21 months after transplanting and tree height was determined after 10,15 and 21 months. Data were averaged across trees within a treatment and sampling date per pasture. These means were then subjected to analysis of variance using a split-split plot design in which time after transplanting was the main plot, competing forage as the first split and tree protection treatment as the split-split plot [24]. Least square means and standard errors were used to compare means. Analysis of variance, means and LSSE were calculated using PROC GLM [24].

Environmental Monitoring. Environmental conditions in 2001 and 2002 were monitored with a Delta-T (Delta-T Devices Ltd., Cambridge, United Kingdom) system consisting of a DL2e logger, an air temperature thermistor, and a relative humidity sensor. Data were collected continuously at $1 \mathrm{~h}$ intervals in 2001 and 2002. Rainfall was measured with a standard rain gauge.

Between 2004 and 2007, meteorological data were recorded at 0.5-h intervals using a weather station (Model 900, Spectrum Technologies, Inc, Plainfield, IL). Daily reference $\mathrm{ET}_{\mathrm{o}}$ was calculated using the Penman-Monteith equation [27] which included air temperature, relative humidity, solar radiation ( $\lambda=300$ to $1100 \mathrm{~nm}$ ), wind speed, latitude, and elevation above sea level from PMmon software [28]. Data for $\mathrm{ET}_{\mathrm{o}}$ were collected at $1.5 \mathrm{~m}$ elevation, not $2 \mathrm{~m}$ as specified [27].

\section{RESULTS}

Experiment 1. Effects of weed control, soil fertilization and irrigation on pine establishment. All loblolly pine seedlings were living 11 months after planting in the 2001-2002 study; thus, survival data were not subjected to statistical analyses. Analysis of variance indicated that the above 
ground fresh weight of seedling trees was significantly affected by the level of weed control, but not significantly affected by irrigation and soil fertilization, or any of the interactions among the three main factors (Table 1). Eleven months after planting, above ground tree fresh weight averaged $201.8 \mathrm{~g}$ for the high level of weed control compared to $92.8 \mathrm{~g}$ for the lower level of weed control (LSSE=7.9 $\mathrm{g}$ ) 11 months after planting. Similar results were found when tree height data were subjected to analysis of variance, except that months after transplanting significantly affected tree height in addition to the level of weed control (data not shown). Tree height was significantly greater three and 11 months after planting (June 2001) for those seedlings managed with the higher level of weed control (Fig. 2).

Table 1. Summary of the Analysis of Variance Examining the Effects of Weed Control, Irrigation and Fertilization on Fresh Weight of Loblolly Tree Seedlings 11 Months After Planting (Experiment 1)

\begin{tabular}{|c|c|c|c|}
\hline Source of Error & $D f^{1}$ & Mean Sum of Squares & F-Value \\
\hline Irrigation (I) & 1 & 2890.0 & 2.33 \\
\hline Weed Control (WC) & 1 & 118810.0 & $95.83 * * *^{2}$ \\
\hline Fertilization $(\mathrm{F})$ & 1 & 32.4 & 0.03 \\
\hline $\mathrm{I}^{*} \mathrm{WC}$ & 1 & 409.6 & 0.33 \\
\hline$I^{*} \mathrm{~F}$ & 1 & 384.4 & 0.31 \\
\hline $\mathrm{WC}^{*} \mathrm{~F}$ & 1 & 32.4 & 0.03 \\
\hline Error & 33 & 1239.9 & \\
\hline
\end{tabular}

$2 * * *$ denotes F-value significant at $\mathrm{P}<0.001$.

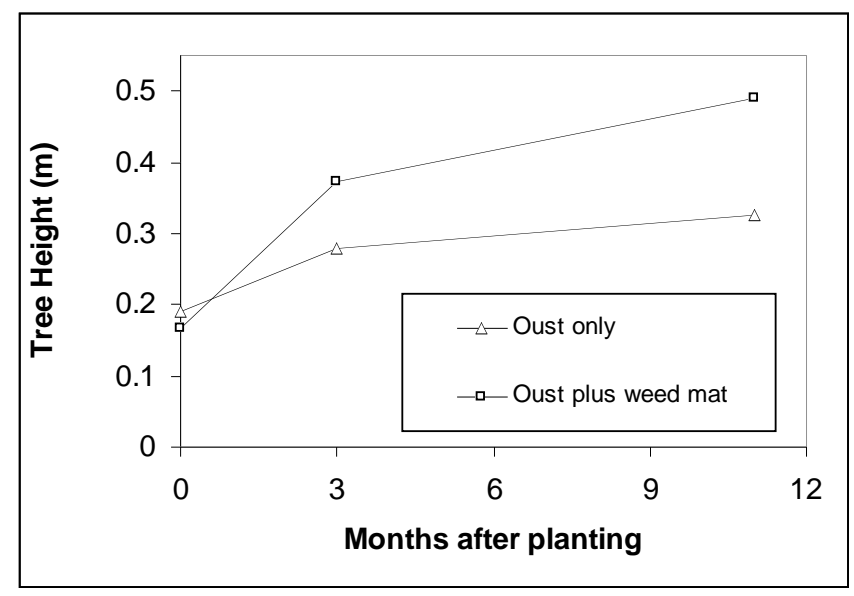

Fig. (2). Effects of two levels of weed control (Oust only and Oust plus weed mat) on loblolly tree height (Experiment 1). Data were averaged across 2 levels of irrigation and 2 levels of soil fertilization. Data symbols are greater than the least square standard error of the mean $(\mathrm{LSSE}=0.011 \mathrm{~m})$.

Experiment 2. Effects of weed control on loblolly seedling growth. The second experiment conducted in 2002 verified the effects of weed control on loblolly tree establishment. Aboveground fresh weight of loblolly seedling trees harvested six months after planting was significantly affected by weed control treatments (Table 2). Tree fresh weight when competing weeds were controlled by the weed mat and two applications of herbicide averaged $220.1 \mathrm{~g}$ compared to $56.8 \mathrm{~g}$ for seedlings in which herbicide applications were the only form of weed control (LSSE $=33.4 \mathrm{~g}$ ). Tree weight for the treatment in which weed control was provided by compost and herbicide was intermediate, averaging $92.6 \mathrm{~g}$.

Table 2. Summary of the Analysis of Variance Examining the Effects of Weed Control on Fresh Weight of Loblolly Tree Seedlings Six Months After Planting (Experiment 2)

\begin{tabular}{|c|c|c|c|}
\hline Source of Error & $D f^{1}$ & Mean Sum of Squares & F-Value \\
\hline Weed Control Treatment & 2 & 38570.72889 & $5.77 * *^{2}$ \\
\hline Error & 15 & 6688.1298 & \\
\hline Total & 17 & & \\
\hline
\end{tabular}

Tree survival was affected by months after planting, weed control treatment and the interaction among weed control treatment and months after planting (Table 3). Tree height was affected by the main effects (months after planting and weed control treatments) but not by the months after planting $\mathrm{x}$ weed control treatment interaction. Tree survival was $100 \%$ in June for all three treatments. Tree survival remained at $100 \%$ for the treatment in which chemical weed control was supplemented with the weed mat. However by September, tree survival declined significantly in the other two treatments, averaged $44.5 \%$ for trees receiving only chemical weed control and $55.3 \%$ for those in which weed control included compost mulching and application of chemicals $(\mathrm{LSSE}=8.2 \%)$. The effects of weed control treatment on tree height were different compared to tree survival. By June, differences in tree height among the three weed control treatments were already significant (Fig. 3). Although differences in tree height in September among the weed control treatments were less than that for tree fresh weight, tree height was a more precise measurement. Thus, both mulching treatments were similarly successful.

Table 3. Summary of the Analysis of Variance Examining the Effects of Months After Planting and Weed Control Treatment on Survival and Tree Heights of Loblolly Pines Seedlings Planted in April 2002 (Experiment 2)

\begin{tabular}{|c|c|c|c|c|c|c|}
\hline \multirow{2}{*}{$\begin{array}{l}\text { Source of } \\
\text { Error }\end{array}$} & \multicolumn{3}{|c|}{ Survival } & \multicolumn{3}{|c|}{ Tree Height } \\
\hline & $D f^{1}$ & $\mathbf{M S S}^{1}$ & F-Value & $D f^{1}$ & MSS $^{1}$ & F-Value \\
\hline Month & 1 & 0.893 & $13.1 * *^{2}$ & 2 & 381.8 & $29.9 * * *$ \\
\hline $\begin{array}{c}\text { Error A } \\
\text { (Month*Rep) }\end{array}$ & 2 & 0.068 & & 3 & 11.2 & \\
\hline Treatment & 2 & 0.298 & $7.25 * *$ & 2 & 210.9 & $9.53 * * *$ \\
\hline $\begin{array}{l}\text { Treatment } \\
* \text { Month }\end{array}$ & 2 & 0.225 & $5.48 * *$ & 4 & 25.1 & 1.06 \\
\hline $\begin{array}{l}\text { Residual } \\
\text { Error }\end{array}$ & 28 & 0.041 & & 40 & 23.8 & \\
\hline
\end{tabular}

${ }^{1}$ Abbreviations: Df, Degrees of Freedom; MSS, Mean Sum of Squares; $2 * *$, and $* * *$ denotes that $\mathrm{F}-\mathrm{V}$ alue is significant at $\mathrm{P}>0.01$ and 0.001 , respectively. 


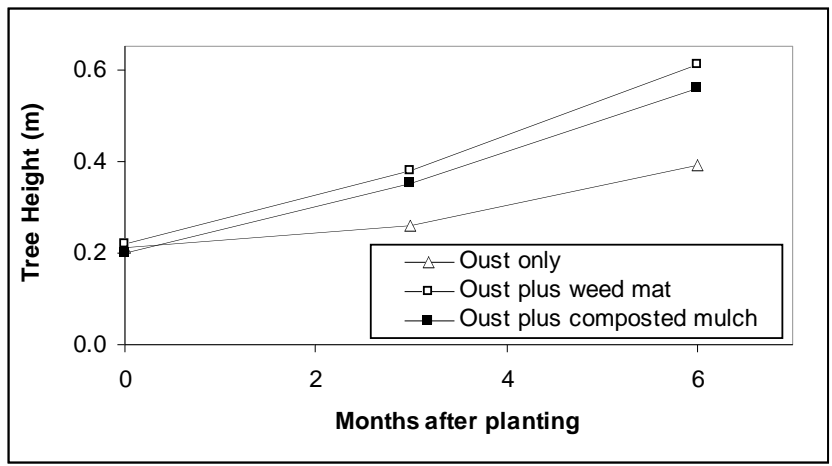

Fig. (3). Effects of weed control treatments (Oust only, Oust plus weed mat and Oust plus composted mulch) on loblolly tree height (Experiment 2). Data were averaged across six replications. Data symbols are greater than the least square standard of the error $(\mathrm{LSSE}=0.03 \mathrm{~m})$.

Climate Data. Monthly means of the maximum daily temperatures $\left(\mathrm{T}_{\mathrm{x}}\right)$ in 2001 and 2002 varied from approximately $10{ }^{\circ} \mathrm{C}$ in December, January and February to approximately $35{ }^{\circ} \mathrm{C}$ July and August (Fig. 4). The maximum for $T_{x}$ occurred over a longer period of time in 2002 extending June through September. Values for PREC varied considerably from month to month in 2001 and 2004 with lowest sums of approximately $1 \mathrm{~cm}$ in August, 2001 and November 2002 to highest sums exceeding $20 \mathrm{~cm}$ in May, and December, 2001, and May 2002.

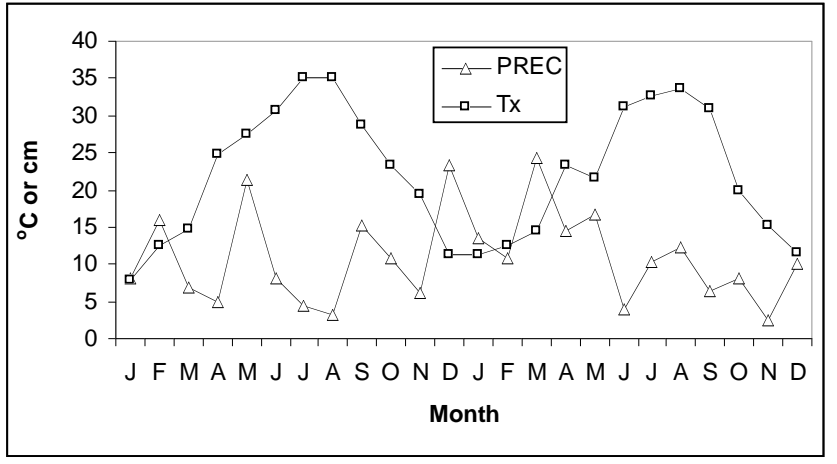

Fig. (4). Monthly means of daily maximum temperature (Tx) and sum of precipitation (PREC) in 2001 and 2002. Months are abbreviated by the first letter in their names.

Environmental data from 2001 and 2002 did not include measurements for solar irradiation, relative humidity, and wind speed need to calculate $\mathrm{ET}_{\mathrm{o}}$. However, those data were available from a weather station located on the research farm from 2004 through 2007. For the data collected in 2004 through 2007, maximum daily relative humidity varied little (data not shown). Thus, the mean monthly maximum relative humidity of $96.6 \%$ was used to predict $\mathrm{ET}_{\mathrm{o}}$ in 2000 through 2002. Monthly means for both wind speed and solar irradiation in 2004 through 2007 followed a seasonal pattern (data not shown). Monthly means from the 2004 through 2007 data set were used as inputs to predict $\mathrm{ET}_{\mathrm{o}}$ from 2001 and 2002. Monthly means for minimum relative humidity in 2004 through 2007 were regressed against monthly means for maximum and minimum daily temperatures, and monthly PREC using PROC GLM [24]. Backward selection (P > $0.10)$ eliminated monthly PREC. The resulting equation was highly significant with F-value for the model of 72.25 (P $<0.001$ ) and R-square of 0.763 . The equation was:

Minimum Relative Humidity = 107.575 - 4.314 (Maximum Temperature) + 4.033 (Minimum Temperature). (Equation 1)

Temperature data from 2001 and 2002 were used as inputs to Equation (1) to predict minimum relative humidity for the prediction of $\mathrm{ET}_{\mathrm{o}}$ in 2001 and 2002. Thus, $\mathrm{ET}_{\mathrm{o}}$ for 2000 and 2001 were estimated from the actual temperature data from 2000 and 2001, and estimates for relatively humidity, wind speed and solar irradiation from the 2004-2007 data set.

The difference between calculated $\mathrm{ET}_{\mathrm{o}}$ and PREC was negative by July in both years (Fig. 5), indicating that $\mathrm{ET}_{\mathrm{o}}$ exceeded PREC by mid-summer. This difference became greater in August in both years. The difference between $\mathrm{ET}_{\mathrm{o}}$ and PREC as greater in 2001 study (Experiment 1) compared to 2002 (Experiment 2).

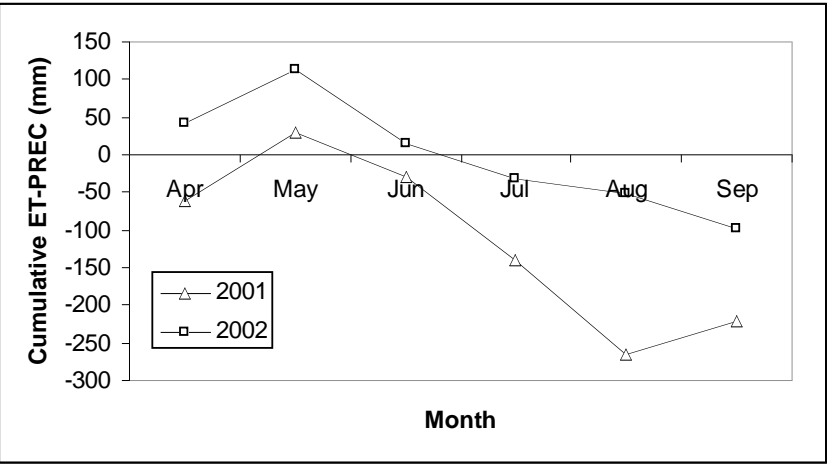

Fig. (5). Changes in the cumulative difference between estimated evapotranspiration $\left(\mathrm{ET}_{\mathrm{o}}\right.$ ) and precipitation (PREC) during the 2001 and 2002 growing seasons. ET $_{\mathrm{o}}$ values were calculated as described in Materials and Methods and Results sections.

Experiment 3. Protection from grazing. Two treatments to protect trees from grazing damage were compared to no protection. These treatments were: 1) exclusion of cattle by a fence; and 2) uspending a strand of electric wire above the tree rows. Tree survival and height were affected by the main effects of time after transplanting, competing forage and tree protection treatment (Table 4). In addition, there were significant interactions among most of the main effect factors. Very few trees survived in pastures where no protection was provided (Fig. 6). Those trees that did survived had no change in tree height between 10 and 21 months after transplanting (Fig. 7). A single strand of electric fence above the tree increased survival markedly over that of no protective treatment (Fig. 6); however, tree height was not significantly different from that of no protection (Fig. 7). Both tree survival and tree height were greatest, when grazing was prevented by a fence enclosure.

Tree survival and height were greater when the competing vegetation was bermudagrass as compared to those when the competing vegetation was tall fescue when protection from grazing was provided. For example, tree survival in fenced enclosures was $79.3 \% 21$ months after transplanting in bermudagrass compared to $54.7 \%$ for those planted in tall fescue sod (LSSE $=5.5 \%)$. Similarly, tree height was 1.95 m 21 months after transplanting into bermudagrass sod when cattle grazing was excluded by a fence enclosure compared 
to $1.22 \mathrm{~m}$ when planted into tall fescue sod (LSSE $=0.07 \mathrm{~m})$. When trees were protected by a single strand of electrified wire and planted into a bermudagrass sod, tree height increased from $0.28 \mathrm{~m} 10$ months after transplanting to $0.40 \mathrm{~m}$ 21 months afterwards. When trees were protected by a single strand of electrified wire and planted into a tall fescue sod, tree height did not change between 10 and 21 months after transplanting, averaging $0.20 \mathrm{~m}$ at both dates $(\mathrm{LSSE}=0.07$ $\mathrm{m})$.

Table 4. Summary of the Analysis of Variance Examining the Effects of Time After Transplanting, Competing Forage and Protection Treatment on Loblolly Pine Tree Survival and Height (Experiment 3)

\begin{tabular}{|l|l|c|c|c|c|c|}
\hline \multirow{2}{*}{$\begin{array}{c}\text { Source of } \\
\text { Error }\end{array}$} & \multicolumn{3}{|c|}{ Tree Survival } & \multicolumn{3}{c|}{ Tree Height } \\
\cline { 2 - 7 } & $\mathbf{D f}^{\mathbf{1}}$ & $\mathbf{M S S}^{\mathbf{1}}$ & F-Value & Df $^{\mathbf{1}}$ & MSS & F-Value \\
\hline \hline Time & 3 & 6095.66 & $113.0^{* * * 2}$ & 2 & 2701.99 & $193.4^{* * * *}$ \\
\hline $\begin{array}{l}\text { Error A } \\
\text { (Time*Rep) }\end{array}$ & 8 & 288.55 & & 6 & 28.38 & \\
\hline Forage & 1 & 14660.82 & $323.3^{* * *}$ & & 4541.2 & $35.63^{*}$ \\
\hline $\begin{array}{l}\text { Error B } \\
\text { (Forage*Rep) }\end{array}$ & 2 & 45.34 & & 2 & 127.46 & \\
\hline $\begin{array}{l}\text { Protection } \\
\text { Treatment } \\
\text { (Trt) }\end{array}$ & 2 & 125941.95 & $350.6^{* * *}$ & 2 & 42663.28 & $528.3^{* * *}$ \\
\hline Forage*Trt & 2 & 6234.28 & $17.4^{* * *}$ & 2 & 2435.25 & $30.16^{* * *}$ \\
\hline Time*Trt & 6 & 967.33 & $2.7 *$ & 4 & 2239.35 & $27.73^{* * *}$ \\
\hline $\begin{array}{l}\text { Forage* } \\
\text { Time*Trt }\end{array}$ & 9 & 162.6 & 0.4 & 6 & 190.10 & $2.3 *$ \\
\hline $\begin{array}{l}\text { Residual } \\
\text { Error }\end{array}$ & 254 & 359.2 & & 190 & 80.75 & \\
\hline
\end{tabular}

Abbreviations: Df, Degrees of Freedom; MSS, Mean Sum of Squares; ${ }^{2 *}$, and ${ }^{* * *}$ denotes that $\mathrm{F}-\mathrm{V}$ alue is significant at $\mathrm{P}>0.05$ and 0.001 , respectively.

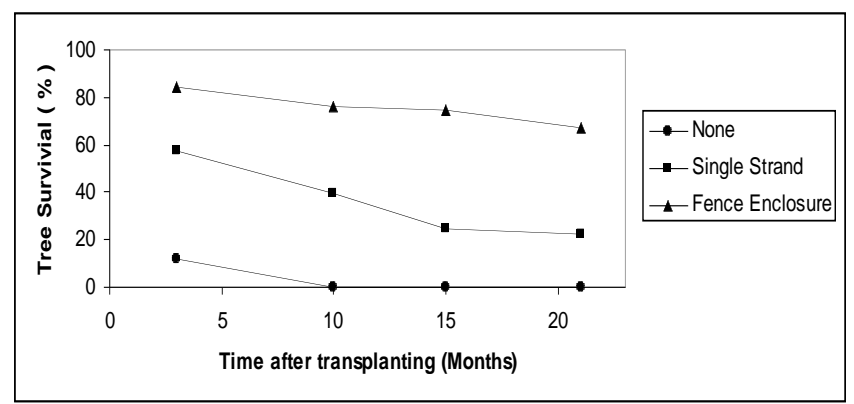

Fig. (6). Effects of tree protection treatments over time after transplanting on loblolly pine tree survival (Experiment 3). Trees were not protected from grazing cattle or protected from grazing by either a single strand of electrified wire suspended above the tree or an electric fence enclosure. LSSE for comparing means is $3.9 \%$.

\section{DISCUSSION}

Results from the first two experiments identified adequate weed control as a critical management factor affecting loblolly pine tree seedling establishment (Tables 1-3; Figs. 2, 3). In these two experiments there were substantial increases in tree survival and growth when the area immediately adjacent to the pine tree was kept devoid of competing vegeta- tion. Weed control with herbicide only resulted in only sparse competing vegetation during the growing season (Fig. 1). However, even low levels of competing vegetation significantly reduced tree height and fresh weight (Figs. 2, 3).

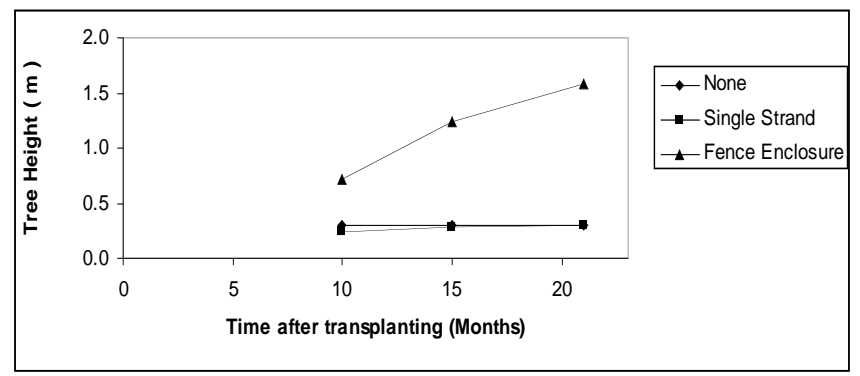

Fig. (7). Effects of tree protection treatments over time after transplanting on loblolly pine tree height (Experiment 3). Trees were not protected from grazing cattle or protected from grazing by either a single strand of electrified wire suspended above the tree or a fence enclosure. LSSE for comparing means is $0.05 \mathrm{~m}$.

There was a significant difference in the results between the two studies. Only tree growth was affected by weed control treatments in the 2001(Experiment 1) with tree survival being high in all treatments, whereas weed control treatments in the 2002 study (Experiment 2) affected both tree survival and growth. This study demonstrated that both survival and growth can be adversely affected by competing vegetation. Differences in estimated $\mathrm{ET}_{\mathrm{o}}$ and PREC during the 2001 and 2002 growing seasons were analyzed to determine if differences in tree survival between the two studies were related to extent of soil moisture deficient during the summer. In both 2001 and 2002, cumulative difference between estimated $\mathrm{ET}_{\mathrm{o}}$ and PREC became negative during the summer and the magnitude of this difference increased as the summer progressed (Fig. 5). These results are consistent with variation in soil moistures observed in a neighboring field in 2002 and 2003 [29]. However, the difference between estimated $\mathrm{ET}_{\mathrm{o}}$ and PREC became negative sooner in the growing season in 2001 (June versus July in 2002) and reached a greater magnitude in 2001 than 2002; however, tree survival was less in 2002. Therefore, there was not an apparent association between annual variations in the difference between estimated $\mathrm{ET}_{\mathrm{o}}$ and PREC and tree survival.

Irrigation was applied eight times to half of the trees in the 2001 study between July 1, 2001 and the middle of September. Each irrigation application was to supply approximately $25 \mathrm{~mm}$ of water to an estimated root zone extending $1 \mathrm{~m}$ from the trunk of the seedling tree. Thus, a total of 200 $\mathrm{mm}$ of irrigation water was applied during the growing season. This level of supplemental water appeared to be sufficient because it approximates the estimated cumulative difference between calculated $\mathrm{ET}_{\mathrm{o}}$ and PREC (Fig. 5).

Loblolly pine seedling survival and growth in pastures was significantly reduced when protection from grazing was inadequate (Table 4; Figs. 6, 7). Trees protected by single strand of electric fence had higher rates of survival than that of no protection, but height of the surviving trees was not different from trees having no protection from grazing. The pine regeneration plot occupied a small area in the continuously grazed, pasture. The grazing livestock seemed to be attracted to the added variety of vegetation in the Oust- 
treated planting rows in the otherwise pure grass stand in the pasture.

The level of damage to pine trees in this study was greater than that observed previously. This tree regenerationcattle grazing study on big bluestem (Andropogon gerardii Vitman) range in Louisiana examined slash pine (Pinus elliottii Engelm) survival, establishment, and growth under three cattle stocking rates-light, moderate, and heavy grazing intensities $[19,20]$. Neither light nor moderate grazing by cattle (33\% and $47 \%$ removal of the current year's forage growth, respectively) affected pine survival or establishment of planted or seeded pines by age 5 years on this slash pinebluestem range under a system of continuous grazing with yearly rotational-burning. However, heavy grazing (56\% removal of the current year's forage growth) significantly reduced the density of planted pines by May of the initial planting year. These differences continued through tree age 18 years on the grazed and ungrazed plots. Survival of seeded pine stands was unaffected by heavy grazing through the study due to the high numbers of seedling established originally.

Another study in Louisiana regarding slash and loblolly pine regeneration was conducted where pines were planted in a 4.5-ha clover-grass paddock that provided supplemental nutrients to cattle during late-fall through early spring [21]. All other grazing by cattle was in the adjoining 320 ha of native bluestem (Andropogon and Schizachyrium species) range. Cattle were allowed in the supplemental paddock only 3 to 4 hours on Monday, Wednesday, and Friday mornings. Under these conditions, cattle grazed only small portions (about 17\%) of the available forage with a substantial portion of the consumed forage being regrowth since the previous grazing period. The slash and loblolly pine plantings treatments included: (1) no protection from grazing, (2) a single electric wire above the pine row, and (3) no grazing (electric fence enclosure). In the absence of protection from grazing, tree damage during the first two years was slight, less than $10 \%$ of the trees. Tree survival and growth was the same when grazing immediately adjacent to the tree was prevented by suspending a single strand of electric fence above the tree row.

King et al. [18] presented a model for predicting damage to pine trees during the first year of establishment as a factor of the amount of forage removed by grazing. Their model predicted that pine damage should be minimal when less than half of the available forage was removed by grazing. In our study, ten months after planting, virtually all of the unprotected trees had died or had been killed and thus few remaining trees were less than half the height of those not subjected to grazing (Figs. 6, 7). The forage utilization in the current study was approximate half [26]; however, the pastures were subjected to continuous grazing, not rotational grazing as in the previous studies. The comparison between the studies suggests that loblolly trees are more likely to be damaged or die when planted into a pasture that is continuously grazed. Further research, however, is needed to substantiate this hypothesis.

\section{CONCLUSION}

Results from this study indicate the successful establishment of a pine silvopasture practice into an existing pasture requires at least two management practices. First, the environment adjacent to the trees needs to be devoid of competing vegetation for optimum tree survival and growth. Second, protection from cattle during the first two years after planting is needed for optimum tree production. This may mean either excluding cattle and harvesting hay for the first two growing season after planting, or practicing rotational grazing at light intensities to reduce pine seedling mortality and growth losses during stand establishment.

\section{ACKNOWLEDGEMENT}

Disclaimer: Product names and trademarks are mentioned to report factually on available data; however, the USDA neither guarantees nor warrants the standard of the product, and the use of the name by USDA does not imply the approval of the product to the exclusion of others that may also be suitable.

\section{ABBREVIATIONS}

$\begin{array}{lll}\mathrm{Df} & = & \text { Degrees of freedom } \\ \mathrm{ET}_{\mathrm{o}}, \quad= & \text { Evapotranspiration } \\ \text { LSSE } & = & \text { Least square standard errors } \\ \text { MSS } & = & \text { Mean sum of squares } \\ \mathrm{PREC} & = & \text { Precipitation } \\ \mathrm{T}_{\mathrm{x}}, & = & \text { Maximum daily temperature }\end{array}$

\section{REFERENCES}

[1] Kline JD, Butler BJ, Alig RJ. Tree planting in the south: What does the future hold? South J Appl Forest 2002; 26: 99-107.

[2] Husak AL, Grado SC. Monetary benefits in a southern silvopastoral system. South J Appl Forest 2002; 26: 159-64.

[3] Ares A, Reid W, Brauer D. Production and economics of native pecan silvopastures in central United States. Agrofor Systems 2006; 66: 205-15.

[4] Lundgren GK, Richard CJ, Pearson HA. An economic analysis of forest grazing on four timber management situations. South J Appl Forest 1983; 7: 119-24.

[5] Burner DM, Belesky DP. Relative effects of irrigation and intense shade on productivity of alley-cropped tall fescue herbage. Agrofor Systems 2008; 73: 127-39.

[6] Adams PR, Beadle CL, Mendah NJ, Smedhurst PJ. The impact of timing and duration of grass control on growth of a young Eucalyptus globulus Labill. plantation. New Forests 2003; 26: 147-65.

[7] Davis MA, Wrage KJ, Reich PB. Survival, growth and photosynthesis of tree seedlings competing with herbaceous vegetation along a water-light-nitrogen gradient. Plant Ecol 1999; 145: 34150 .

[8] Dubois MR, Chappelka AH, Robbins E. Tree shelters and weed control: Effects on protection, survival and growth of cherrybark oak seedlings planted on a cutover site. New Forests 2000; 20: 10518.

[9] Gakis S, Mantzanas K, Alifragis D. Effects of understory vegetation on tree establishment and growth in silvopastoral system in northern Greece. Agrofor Systems 2004; 60: 149-57.

[10] Davies RJ. The importance of weed control and the use of tree shelters for establishing broadleaved trees on grass-dominated sites in England. Forestry 1985; 58: 167-80.

[11] Gilman EF. Effect of nursery production method, irrigation, and inoculation with mycorrhizae-forming fungi on the establishment of Quercus virginiana. J Arboricult 2001; 27: 30-8.

[12] Forrest Keeling Nursery [from home page of Internet]. The Four Step Sequence in the Walk-A-Way-Planting System. [Cited March 31, 2008]. Available from: http://www.fknursery.com/wetlandresto ration/default.asp

[13] Haywood JD. Durability of selected mulches, their ability to control weeds, and influence growth of loblolly pine seedlings. New Forests 1999; 18: 263-76. 
[14] Blazier MJ, Hennessey TC, Dougherty P, Campbell P. Nitrogen accumulation and use by a young loblolly pine plantation in southeast Oklahoma: Effects of fertilizer formulation and date of application. South J Appl Forest 2006; 30: 66-78.

[15] Pardos M, Royo A, Pardos JA. Growth, nutrient, water relations and gas exchange in a Holm oak plantation in response to irrigation and fertilization. New Forests 2005; 30: 75-94.

[16] Jokela EJ, Wilson DS, Allen JE. Early growth responses of slash and loblolly pine following fertilization and herbaceous weed control treatments at establishment. South J Appl Forest 2000; 24: 2330.

[17] Lewis CE, Burton GW, Monson WG, McCormick WC. Integration of pines and pastures for hay and grazing. Agrofor Systems 1984; 2: 31-41.

[18] King DR, Bailey RL, Walston PW. Predicting cattle damage in first year loblolly pine plantations. J Range Manage 1978; 31: 234-5.

[19] Grelen HE, Pearson HA, Thill RE. Establishment and growth of slash pine on grazed cutover range in central Louisiana. South J Appl Forest 1985; 9: 232-6.

[20] Pearson HA, Whitaker LB, Duvall VL. Slash pine regeneration under regulated grazing. J Forest 1971; 69: 744-6.

[21] Pearson HA, Baldwin VC, Barnett JP. Cattle grazing and pine survival and growth in subterranean clover pasture. Agrofor Systems 1999; 10: 161-8.

[22] Baker JB, Langdon OG. "Loblolly Pines" In: Burns RM, Honkala BH, Eds. Silvics of North America, Conifers. Agriculture Hand- book 654. USDA/ U.S. Forest Service, Washington DC: USA 1990; Vol. 1: pp. 1018-51.

[23] Garner BA, Cox JB, Vodrazka FM, Winfrey AL. Soil Survey of Logan County, Arkansas. USDA, National Cooperative Soil Survey/ USDA, Washington DC, USA 1980.

[24] SAS Institute, Inc. SAS/ETS1 User's guide, Version 8. SAS Institute, Inc., Cary NC 1999.

[25] Kimmons TE, Phillips M, Brauer D. Small farm scale production of aerobic compost from hardwoods predigested by Lentinula edodes. J Sustain Agric 2003; 23: 109-23.

[26] Brown MA, Brown AH, Jackson WG, Meisner JR. Genotype x environment interactions in Angus, Brahman, and reciprocal-cross cows and their calves grazing common bermudagrass, endophyteinfected tall fescue pastures, or both forages. J Animal Sci 2000; 78: 546-51.

[27] Allen RG, Pereira LS, Raes D, Smith M. Crop evapotranspiration, guidelines for computing crop water requirements. FAO irrigation and drainage paper 56. Food and Agriculture Organization of the United Nations, Rome 1998.

[28] Snyder RL, Eching S (2003) PMday, Penman-Monteith daily. The Regents of the Univ. California, Davis, California. [Cited $25 \mathrm{Feb}$ 2008]. Available from: http://biomet.ucdavis.edu/Evapotranspiratio n/PMdayXLS/PMday.xls

[29] Brauer D, Horton T, Burner DM. Effects of understory management and forage species on soil moisture in a pecan alley cropping practice. Ann Report North Nut Growers Ass 2004; 95: 27-37. 